In Dr Dunlop's Table I she omits Ellis \& Mellsop's (1985) criterion (C): "The other person had been the first to fall in love". Had this been applied, it would perhaps have been made clear that neither patient believed the object to be in love with her.

This diagnostic confusion stems from ambiguous usage of the term 'erotomania' to include a wide variety of types of pathological attachment behaviour. It is sometimes taken to indicate delusional love by the patient for another person, although in the de Clérambault syndrome the belief is of a love which is in precisely the opposite direction, i.e. from the object to the subject.

Enoch \& Trethowan (1979) remarked on the importance of distinguishing erotomania from everyday infatuation, normal passion, and nymphomania on the one hand, and paranoid schizophrenia on the other, but in the absence of clear definitions it becomes impossible to make these distinctions. Seeman (1978) pointed out that there is much overlap in the literature as to what is meant by the terms phantom lover syndrome, erotomania, and de Clérambault's syndrome. The resulting uncertainty is amply demonstrated in Ellis \& Mellsop's (1985) review of 58 cases, supposedly of de Clérambault's syndrome, of which only 11 (19\%) fulfilled the 'fundamental postulate' criteria (A, B, C, and D) which they adopted.

Cherry Knowle Hospital

Simon EMINSON

Ryhope, Sunderland

Tyne \& Wear SR2 ONB

TIM GiLleTt

St Nicholas Hospital

Gosforth

Newcastle

Roferences

Ellis, P. \& Mellsop, G. (1985) De Clérambault's syndrome-a nosological entity? British Journal of Psychiatry, 146, 90-95.

ENOCH, M. D. \& TRETHOWAN, W. H. (1979) Uncommon Psychiatric Syndromes (2nd edn). Bristol: John Wright.

LOVETt Doust, J. W. \& CHRiste, H. (1978) The pathology of love; some clinical variants of de Clérambault's syndrome. Social Science and Medicine, 12, 99-106.

SEEman, M. V. (1978) Delusional loving. Archives of General Psychiatry, 35, 1265-1267.

Signer, S. F. \& Cummongs, J. L. (1987) De Clérambault's syndrome in organic affective disorder. British Journal of Psychiatry, 151, 404-407.

\section{Post-traumatic stress disorder}

SIR: McFarlane's account of a bushfire (Journal, February 1989, 154, 221-228), while elegant in its methodology, is perhaps not capable of generalisation to post-traumatic stress disorder (PTSD) as a whole. He points out that most of the recent litera- ture focuses on Vietnam veterans and victims of disaster. These groups, however, differ significantly from Dr McFarlane's. Vietnam veterans were an unmotivated, socially disadvantaged group of draftees who were hardly prepared for what they faced, and victims of a disaster are a more heterogeneous group and are, by definition, completely unprepared for the trauma they experience. Dr McFarlane describes his group as large, trained and volunteer. They were recruited into the traumatic event after it started, were well motivated, and possibly had previous experience. It thus, by definition, lacked the element of surprise and unfamiliarity experienced by the other PTSD groups examined.

It may well be that this element of unpreparedness would account for the development of PTSD in some sufferers.

\section{Reaside Clinic \\ Bristol Road South \\ Rubery, Rednal \\ Birmingham B45 9BE}

\section{Neuronal misconceptions}

SiR: Goodman (Journal, March 1989, 154, 292-299) has set himself the difficult task of suggesting that anomalous neural connections underlie some psychiatric disorders. He has commendably suggested tests for his hypothesis. Nevertheless, it suffers from inherent difficulties. Firstly, it incorporates a two-stage pathogenesis: a primary lesion (e.g. brain damage) followed by maladaptive neuronal repair. The dual abnormalities would be more difficult to test in the clinical setting than more simplistic explanations, such as 'neuro excess' theories. Secondly, his attempts to explain a range of psychiatric abnormalities on the basis of misconnections have forced him to make simplistic generalisations, e.g. the dichotomisation between focal and diffuse misconnections, and their likely consequences. If, as he implies, abnormal (and by inference, random) misconnections lead to behavioural abnormalities, it is unlikely that such abnormalities take the form of consistent syndromes. Finally, a misconnection theory need not exclude other hypotheses. Indeed, 'misconnections' could lead to 'neuroexcess' or 'neurodeficiency'.

The relationship between temporal lobe epilepsy (TLE) and schizophrenia illustrates the difficulty of proving or disproving hypotheses of the sort proposed by Dr Goodman. While TLE has been associated with a number of psychiatric states (Vasquez, 1952), its link with schizophrenia has been debated (Small et al, 1986). Dr Goodman focuses on the increased prevalence of schizophrenia among 
patients with TLE due to alien tissue lesions, but neglects other factors which appeared to play an equally prominent role in Taylor's series, viz., sinistrality and femininity (Taylor, 1975). While the discrepancies in prevalence of schizophrenia between alien tissue lesions and mesial temporal sclerotic lesions may be attributed to differences in the likelihood of misconnections following these two lesions, other explanations cannot be ignored. These include differences in the topography of the two types of lesions. Moreover, temporal lobe alien tissue lesions may be accompanied by similar lesions in other brain regions. The latter could account for the psychopathology. A more provocative explanation for the alien tissue/mesial sclerosis discrepancy-that mesial sclerosis arising from perinatal lesions protects against schizophrenia - may not be acceptable to proponents of the aetiological role of obstetric trauma in schizophrenia (Murray et al, 1988).

Western Psychiatric Institute and Clinic

V. L. NIMGAONKAR

$38110^{\prime}$ 'Hara Street

Pittsburgh, PA 15213, USA

\section{References}

MurRAY, R. M., LeWIS, S. W. \& ReVeley, A. M. (1985) Towards an aetiological classification of schizophrenia. Lancet, $i, 1023-1026$

Small, J. G., Small, I. F. \& Hoyden, M. P. (1966) Further psychiatric investigations of patients with temporal and non-temporal lobe epilepsy. American Journal of Psychiatry. 123, 303-310.

TAYLOR, D. C. (1975) Factors influencing the occurence of schizophrenia-like psychosis in patients with temporol lobe epilepsy. Psychological Medicine, 5, 249-254.

VAsQUEZ, J. (1952) Epilepsies temporales et manifestations mentales. Union Medicale du Canada, 81, 1062-1068.

\section{Unreliable urine samples}

SIR: I was very interested to read the results of Gossop et al's follow-up of opiate addicts after treatment (Journal, March 1989, 154, 348-353). I am, however, a little unhappy about their use of urine specimens to support claims of abstinence, as in my experience such testing is not sufficiently reliable for such inferences to be drawn. It is difficult, without undue strain to the doctor-patient relationship, to be sure of the origins of a proffered sample. I feel that urine drug screening is often a test of uncertain accuracy, performed on a sample of dubious antecedents, provided by a population noted for the deviousness of their behaviour. It has a place in the assessment of drug use, but added little to Dr Gossop et al's study.

Queen's Medical Centre

STEVE BROWN

University Hospital

Nottingham NG7 2UH

\section{Munchausen's syndrome by proxy}

SIR: Munchausen's syndrome by proxy has been called the "hinterland of child abuse" (Meadow, 1977) and there have been numerous, and sometimes quite bizarre, case descriptions. The parents are known, by using fabrication and manipulation, to cause their children to receive unnecessary and potentially harmful investigations and treatment. The presenting problems can vary widely and include neurological symptoms, haematuria and bacteriuria, recurrent diarrhoea and bloody stools, vomiting, dehydration, drowsiness, and urticaria. The management of this disorder can present quite a challenge to health professionals (Nicol \& Eccles, 1985; Rosen et al, 1983). I report a case with an unusual presentation of self-induced vomiting, anorexia, and weight loss in a 3-year-old girl.

Case report: A 3-year-old girl was admitted to the paediatric ward via her general practitioner, after having been ill for 5 days with an upper respiratory tract infection and perhaps a mild chest infection, for which she had been treated with amoxycillin. This would not in itself have merited admission, but the girl's mother complained that the girl was refusing to eat or drink, and was making herself vomit by "sticking her finger down her throat", hence becoming dehydrated. The girl had been admitted to a hospital in Leeds nine months before this admission and had presented with "vomiting and food refusal". Her mother was very concerned about the child's condition, and repeatedly asked the doctors to set up a drip as she felt her child was "very dehydrated".

Child psychiatric opinion was sought, and it soon became clear that the child's mother was suffering from bulimia nervosa. She gave clear descriptions of bingeing and selfinduced vomiting since she was a teenager. Her life had been unsettled and her relationships short-lived. Her child's father left before the child was born, and the mother then lived with another man with whom she had another child. He also left, after much conflict at home, and took their two-year-old girl with him. Now the mother is seeing another man and is pregnant again.

She described her own childhood as "terrible", as her own mother died from "not eating" and she and her sister were brought up from an early age by her maternal grandmother, who was very strict and would beat the children "until they stopped crying". The mother left home as soon as she could and tried to pass examinations in nursing but was unsuccessful. She worked as an auxiliary nurse before having her first baby. She has had numerous admissions into various hospitals for short spells with "non-specific" problems, leaving the child in voluntary care or with friends. Her last admission was for suspected ectopic pregnancy after she collapsed on the paediatric ward while visiting her daughter, who had been readmitted with selfinduced vomiting. The mother was discharged after a short period of observation.

We encouraged the mother to attend for individual psychotherapy, with a view to helping her cope with 